\title{
Reflections upon an employability initiative at an English post-92 business school
}

\author{
James Rattenbury, Yvonne Rennison, Fiona McEwen and Hannah \\ Holmes, Manchester Metropolitan University \\ Email: J.Rattenbury@mmu.ac.uk \\ DOI: http://doi.org/10.5456/WPLL.20.1.179
}

\begin{abstract}
This innovative practice paper describes and reflects upon an intervention aiming to improve the employability outcomes of business school students. Final year students from the Accounting \& Economics department of a post- $92^{1}$ university in north-west England were invited to join an employability initiative. The paper's findings include that the take-up of this voluntary scheme was small relative to the department cohort's size. This volunteer group was self-selecting and therefore subsequent attendance was generally good. The scheme was however unsuccessful in engaging with 'harder to reach' students i.e. those most in need of support. We argue that employability teaching could be embedded within the curriculum through more 'real world' contexts or through a compulsory credit-bearing unit. Delivering similar courses would require substantial resource to scale up delivery. A number of practical lessons were learned from our experiences. This paper will interest those considering implementing employability curricula in higher education.
\end{abstract}

Key words: employability, higher education, widening participation.

\section{Introduction - Improving employability prospects for graduates at a UK business school}

This article reports the outcome of a small-scale undergraduate employability intervention aimed at improving employability outcomes for students, and more fully understanding students' perceptions of employability. The intervention took place in the Accounting, Finance \& Economics department at a post- $1992^{\mathrm{i}}$ university business school in northwest England. Firstly, we will discuss the role of employability within the policy discourse in United Kingdom higher education. 
We argue that despite the increasing number of both graduates and universities in the UK, the stratification of universities has remained. League tables from newspapers such as The Times rank universities based upon criteria such as academic research output through the Research Excellence Framework (REF), and student satisfaction through the National Student Survey (NSS) (Savage et al., 2015). Another feature in the UK is the publication by government of key performance measures (HESA, 2016). The key employability measure is the Destination of Leavers of Higher Education (DLHE) data. This survey of all UK graduates captures destinations six months after graduation, i.e. whether they are in employment, so-called 'graduate employment' or further study. The importance of employability of graduates has received greater prominence as UK legislation in 2017 introduced the Teaching Excellence Framework (TEF) (Higher Education Funding Council for England, 2017). This is a measure of teaching quality in UK Higher Education (HE) institutions. One of the TEF metrics is graduate outcomes (DLHE data) and a satisfactory TEF outcome will now allow HE institutions to increase student tuition fees. We argue that these factors will increase pressure on HE institutions to improve their employability outcomes. The pressure on HE is not only a UK phenomenon. The Australian Government recently proposed that from $2019,7.5 \%$ of university funding will be tied to performance and one of the components of the performance will be related to employability (Australia Bulletin, 2017). This proposal was subsequently deferred and future policy remains uncertain. This incident highlights the controversial and complex nature of the debate in this area of HE policy.

It is therefore within this context that the university is seeking to address its employability measures. As a post-92 university, the department has pursued a successful 'widening participation in HE' agenda. It has increased course admissions and graduate numbers, however its graduates can find accessing the accounting and economics professions challenging. Employability DLHE data subsequently remains below its university target.

In the following sections, we describe the employability intervention designed to address these issues. We present the study findings, consider the issues of embedding employability in the curriculum, and discuss the practical problems encountered and how they were overcome. 


\section{Attempting to increase the DLHE data results through an 'employability boot camp' intervention}

In 2014, DLHE employability metrics were published for the 2012-13 cohort. These were lower than the target set for the department by the university. In an attempt to improve the measures, a pilot 'employability boot camp' intervention was implemented by a small group of lecturers/researchers. Funding for the intervention was secured from the business school's intervention budget. This boot camp was a voluntary scheme and was advertised to students by flyers, and promoted to approximately 500 final year students in lectures and electronic media. Over three academic years, a small group of the final year students volunteered each year to attend six 2-hour sessions (Cohort 1: 2014-15. Cohort 2: 201516. Cohort 3: 2016-17). The programme was designed by the lecturers/researchers to enhance student employability. The activities were included to add skills that we, as experienced professionals, felt that students would benefit in developing. The course details and justification for its inclusion appear in Table 1.

Table 1 Employability boot camp programme

\begin{tabular}{|l|l|l|}
\hline Session & Activity & $\begin{array}{l}\text { Reason we (the intervention group) included } \\
\text { the activity in the 'boot camp' }\end{array}$ \\
\hline 1 & $\begin{array}{l}\text { Social media } \\
\text { training }\end{array}$ & $\begin{array}{l}\text { To raise the students' awareness of maintaining } \\
\text { their public profile, 'personal brand' and to } \\
\text { implicitly consider their 'social capital'. }\end{array}$ \\
\hline 2 & Museum trip & $\begin{array}{l}\text { To introduce and develop (in non-academic } \\
\text { language) the concept of cultural capital. }\end{array}$ \\
\hline 3 & Presentation skills & $\begin{array}{l}\text { The students prepared a 5-minute PowerPoint } \\
\text { presentation, based upon their museum visit } \\
\text { experience. This was presented to their student } \\
\text { peer group and to a drama coach, who } \\
\text { reviewed their presentation skills. We felt that } \\
\text { the ability to present confidently is a key } \\
\text { employability skill. }\end{array}$ \\
\hline 4 & $\begin{array}{l}\text { Discussion about } \\
\text { leadership plus } \\
\text { military initiative } \\
\text { exercises with the } \\
\text { local university } \\
\text { Officer Training } \\
\text { Corps (OTC) }\end{array}$ & $\begin{array}{l}\text { The OTC provides military and officer skills } \\
\text { training for HE students. We supposed the } \\
\text { students might lack leadership skills and } \\
\text { 'mental resilience'. We also presumed that } \\
\text { students might not have previously experienced } \\
\text { a military environment and culture. }\end{array}$ \\
\hline
\end{tabular}




\begin{tabular}{|l|l|l|}
\hline 5 & $\begin{array}{l}\text { Curriculum Vitae } \\
\text { (CV) training and } \\
\text { mock job } \\
\text { interviews }\end{array}$ & $\begin{array}{l}\text { The students' CVs were reviewed by the } \\
\text { Careers and Employability Service. Mock } \\
\text { interviews were conducted by senior academic } \\
\text { and admin staff. Written feedback was offered } \\
\text { to students. The purpose was to expose } \\
\text { students to the interview process and build } \\
\text { confidence in interviews. }\end{array}$ \\
\hline 6 & $\begin{array}{l}\text { End-of-course meal } \\
\text { and networking } \\
\text { opportunity }\end{array}$ & $\begin{array}{l}\text { This was to reward the students for their } \\
\text { engagement and efforts. We also invited senior } \\
\text { staff members, prospective employers and } \\
\text { external examiners to the meal. This was to } \\
\text { give students an opportunity to develop social } \\
\text { capital, and to give them experience of } \\
\text { business networking and exposure to 'business } \\
\text { etiquette'. }\end{array}$ \\
\hline
\end{tabular}

We (the research team) noted that despite extensive promotion of the boot camp to students, from a possible cohort of approximately 500 students per year, there were only 12-15 volunteers from each year. The lack of student engagement with the course made us reflect on what type of students were attracted to join this course and more generally, why students choose to engage in university employability initiatives. We did undertake an exploratory study into this question, which will appear in the Findings section.

\section{Findings}

We did not make specific claims for the initiative, i.e. we did not devise criteria to measure whether the initiative was a success. We noted that the DLHE data for the following academic year (2013-14) did show an increase in students in 'employment' and 'graduate employment' year-on-year, but we would not claim that the initiative caused this increase; the boot camp participants represented a small fraction of the cohort of graduates. We presumed that the increase was due to the upturn in the UK economy and graduate job market. Data on the destination of Cohort 2 attendees was collected. Of the twelve who had attended and responded to the enquiry, nine reported they were in employment, and three were in full-time study. Five students from Cohort 2 submitted a reflection on their experiences. The broad findings were that the students found aspects of the boot camp enjoyable and identified key incidents where they had gained insights into their current skills and experiences. Three students over the two boot camp cohorts were also interviewed in more depth to understand their motivations for attending and 
their career aspirations. Using this interpretivist methodology revealed participants' influences and motivations were highly complex and nuanced. Themes they reported included both structural factors e.g. class, gender and cultural factors around ethnicity. We would not make claims to generalise findings on such a small sample. A larger longitudinal quantitative study of students is being undertaken.

\section{Considering embedding employability within the curriculum}

The boot camp experience contributes to the debate as to whether employability should be embedded into the wider curriculum, and if so, how. One might argue that take-up was disappointing because the boot camp was stand-alone and should therefore be embedded as a compulsory part of a wider programme. We note that delivering a short course of this type is resource intensive, so scaling up delivery to cohorts of hundreds would be more costly than normal teaching, so resources would need to be made available. Additionally, much good teaching and learning of this employability material is already delivered in the business school's Professional Development Week ${ }^{\mathrm{ii}}$, so duplication of effort would occur if both took place. One could argue that those who attend an optional course will get more benefit than those being required to do it. We would argue that this initiative is innovative practice, due to the concentrated nature of the course and the attempt to develop a group ethos to learning, identity, meaning and practice, similar to a Community of Practice (Wenger, 1998). This motivation and engagement may well be lost if this teaching was made compulsory for students.

Another factor to consider is the nature of vocational degree courses with professional body exemptions. Accounting and finance degree courses are designed typically to gain maximum exemptions from professional accounting body qualifications. This therefore restricts scope for nontechnical material in the curriculum. There is a risk that vocational students may disengage because they might not see the point of non-relevant, nonassessed material on their course.

When considering these factors, course designers should be mindful of the National Student Survey. This is an external survey that measures student satisfaction. This is another key metric for the Teaching Excellence Framework. There is therefore a dilemma to reconcile what academics feel is good for students and what students value when completing this survey. 
Maintaining the student experience is rightly important, but we suggest that students may not always see the benefits of parts of the curriculum at the time.

We conclude that an employability focus can be usefully incorporated within curricula and could lend 'real world' context to studies. Another option might be to include employability credit-awarding courses and have them delivered by personal tutors. Academic texts might be used to underpin learning skills around reflection (Cottrell, 2010).

\section{Practical problems encountered, solutions found and lessons learned}

We anticipated that maintaining student attendance would be a problem, however this did not materialise. As the scheme was voluntary, the students were self-selecting and proved to be very committed. A team spirit quickly developed in the group and this encouraged students to keep attending although attendance was admittedly less successful with Cohort 3. We were very clear from the outset about the need for professional behaviour, e.g. nonattendance without prior notice would mean them losing their place. The course ran on a Wednesday afternoon, when no lectures were scheduled. Scheduling on other days would not have been possible due to timetabling commitments.

Coordinating the various outside speakers was complex and timeconsuming the first time that the course ran. This became easier the second time though, as contributors became used to what we expected of them. We appreciated the commitment from colleagues who were prepared to give up their time from their schedules to make the initiative possible. We found that having four members of the team was necessary to deliver the project. This was due to managing all of our other various work commitments. The academic team needed commitment and enthusiasm to deliver the scheme, but we found that it was a rewarding experience.

\section{Conclusions}

League tables and performance metrics are increasingly important features of the UK education policy, as seen in examples of recent UK government White Papers ${ }^{\mathrm{iii}}$ (Department for Business Innovation and Skills, 2016; Department for Education, 2016) and legislation (Department for Education, 2017). These national policies strongly inform university and departmental policy. It is in this context that we attempted to both indirectly improve the 
DLHE measures and more fully understand students' perceptions of the employability discourse.

One practical issue was to understand why the boot camp did not attract the interest of more students. We conclude that the student cohort is highly diverse and the influences of students are numerous and nuanced, so we do not make generalisable conclusions on how students behave. To assume that all students share the same motivations as policymakers would be incorrect and lead to misinterpretation of student behaviour. Essentially, the employability message from government and university may not resonate with all students, who often have different priorities at this time in their lives. Further efforts at exploring the motivation of boot camp participants compared to non-participants might help in identifying and engaging 'harder to reach' students. We suggest that policymakers, professional bodies and large employers may improve employability outcomes in the longer term if they remain aware of the motivations of these students.

In conclusion, DLHE measures seem to confirm that improving employability indicators remains a challenge at many HE institutions pursuing a widening participation agenda (Brown, 2013). We argue however against a 'counsel of despair'. Small-scale interventions are worthwhile because, at an individual level, students have experienced success due to their boot camp experiences. As a postscript, we recently received a message from one of the 2016 graduates and a boot camp alumnus. She had just been promoted from a clerical role to a trainee finance analyst, and was about to start studying for professional accounting exams. Although career responsibility ultimately lies with the graduate, we hope that the work of academics and career professionals plays some part in their success.

\section{End Notes}

\footnotetext{
'A 'post-92 university' is a higher education institution that was formerly a polytechnic and was awarded university status in 1992. They are generally institutions traditionally specialising in technical and vocational subjects and typically pursue a widening participation agenda.

ii The Professional Development Week in this university is a mid-term week without teaching and devoted to developing professional and employability skills. These classes are not compulsory and not assessed.

iii A 'White Paper' is a publication issued by the UK government as a precursor to legislation.
} 


\section{Acknowledgements}

We thank those who volunteered to support this initiative. We also give to the students who attended the course, our best wishes for their future careers.

\section{References}

Australia Bulletin (2017) Should university funding be tied to student performance? [Online]. Available at australiabulletin.com/2017/04/02/should-university-funding-be-tied-tostudent-performance (Accessed 27 June 2017]

Brown, P. (2013) 'Education, opportunity and the prospects for social mobility', British Journal of Sociology of Education, vol. 34, no. 5-6, pp. 678-700.

Cottrell, S. (2010) Skills for Success: The Personal Development Planning Handbook, Basingstoke: Palgrave Macmillan.

Department for Business Innovation \& Skills (2016) Success as a Knowledge Economy: Teaching Excellence, Social Mobility \& Student Choice (White Paper). London: The Stationery Office (Cm 9258).

Department for Education (2016) Educational Excellence Everywhere (White Paper). London: The Stationery Office (Cm 9230).

Department for Education (2017) Higher Education and Research Act 2017

[Online]. Available at

www.legislation.gov.uk/ukpga/2017/29/contents/enacted/data.htm (Accessed 26 June 2017).

HESA (2016) Key Information Set Record 2016/17 [Online]. Available at https://www.hesa.ac.uk/collection/c16061 (Accessed 27 May 2016)

Higher Education Funding Council for England (2017) TEF for providers [Online]. Available at www.hefce.ac.uk/lt/tef/tefproviders/ (Accessed 26 June 2017).

Savage, M., Cunningham, N. and Devine, F. (2015) Social Class in the 21st Century, London: Penguin Books.

Wenger, E. (1998) Communities of Practice: Learning, Meaning, and Identity, Cambridge: Cambridge University Press. 